\title{
Manajemen Usahatani Salak Bali Organik di SubakAbian Kebon Desa Nongan Kecamatan Rendang Kabupaten Karangasem
}

\author{
NI WAYAN SUDIARMINI, NI WAYAN SRI ASTITI, \\ NYOMAN PARINING \\ Program Studi Agribisnis, Fakultas Pertanian, Universitas Udayana \\ Jl. PB. Sudirman 80323 Denpasar \\ E-mail : sudiar_mini@yahoo.com \\ wayansriastiti@yahoo.co.id
}

\author{
Abstract \\ Management of Organic Salak Farming System in Nongan Village, \\ Rendang Sub-district, Karangasem Regency
}

Farm management covers the management functions that include: planning, organizing, implementation and monitoring of the production process. This process is related to the plant maintenance to the marketing. It is expected that through the implementation of farm management function, farmers in Subak Abian Kebon will be able to carry out farming activities well and to increase the farmers' income for the common welfare. The purpose of this study is to determine the implementation of management functions in the salak (snake fruit) farming activities in the Subak Abian Kebon. The location of the research was in Subak Abian Kebon of the Nongan Village, Rendang Sub-District, Karangasem Regency, taken by purposive sampling. The total population is 76 people and the number of respondents is 44 people taken based on the Slovin formula. Data analysis used is qualitative descriptive analysis. The results showed that management functions in farming activities in the Subak of AbianKebon can be classified as very good with the score achievement of 3.9. This is proven by the good farming planning with the achievement score of 4.0, good farming organization with achievement score of 4.0 , the implementation of farming is very good with achievement score of 4.3 and supervision that can be categorized as moderate, with the achievement score of 3.4. It can be suggested that the subak members should be able to improve supervision on the production quality and the government is expected to pay attention to the market access for subak in order to increase the demand for the fruits considering that Nongan Village is a tourist route to Besakih Temple.

Keywords: management activities, snake fruit farming, Subak Abian

\section{Pendahuluan}

\section{I.I Latar belakang}

Salak atau nama latinnya Salacca Edulis Reinw merupakan tanaman perkebunan buah-buahan tropis asli Indonesia. Salak mempunyai warna kulit putih kekuningan sehingga disebut salak putih, bentuk buahnya bulat, dan ukurannya kecil renyah. Salak yang terkenal di Bali adalah Salak Gula Pasir. Rasa manis ini sudah ada sejak buah salak itu masih kecil dan masih muda. Warna kulit buahnya coklat kehitaman dan 
bersisik kecil-kecil. Daging buahnya tebal dengan kandungan air sedikit dan berbiji kecil-kecil. Salak ini berasal dari Desa Sibetan, Karangasem, Bali (Nazaruddin dan Regina, 1992).

Perkebunan atau lahan kering yang dimiliki Kabupaten Karangasem pada tahun 2015 seluas $30.669 \mathrm{~km}^{2}$ dan luas panen buah salak di Kecaman Renang 7.058.904 pohon dengan produksi $24.389,00$ ton salak. Kecamatan Rendang dengan luas panen 249.864 ha memproduksi 1.154,00 ton buah salak (BPS Kabupaten Karangasem Bali, 2015).

Lahan kering atau perkebunan di Bali disebut dengan subak abian. Subak abian merupakan suatu persekutuan masyarakat hukum adat mempunyai wilayah serta harta kekayaan sendiri dan berhak mengatur rumah tangganya sendiri (otonom), yang bersifat sosio, agraris, religius, dan ekonomis bergerak dalam bidang pertanian lahan kering. Sebagaimana halnya dengan berbagai organisasi tradisional yang tumbuh di Bali, subak juga berdasarkan atas filosofi Tri Hita Karana. Filosofi ini mengajarkan bahwa kebahagian manusia akan dapat dicapai bila manusia mampu menjaga keharmonisan hubungan antara tiga faktor dari Tri Hita Karana, yaitu parhyangan (unsur ketuhanan), pawongan (manusia), dan palemahan (unsur alam) (Dinas Kebudayaan Provinsi Bali, 2006).

Subak Abian Kebon merupakan salah satu organisasi masyarakat di Desa Nongan, Kecamatan Rendang, Kabupaten Karangasem. Subak Abian Kebon, memiliki luas lahan 46 hektar, dengan anggota 76 orang. Pada subak ini terdapat dua jenis tanaman salak yaitu, Salak Bali dan Salak Gula Pasir. Desa Nongan merupakan salah satu desa penghasil salak yang telah melakukan usahatani salak selama beberapa tahun. Namun usahatani tersebut kebanyakan masih bersifat tradisional, hal ini berpengaruh pada produktivitas dan rendahnya pemasaran salak. Suatu yang patut disayangkan mengingat usahatani salak memerlukan penanganan yang khusus sejak persiapan hingga dipasarkan, karena itulah pentingnya melakukan suatu manajemen usahatani di Subak Abian Kebon.

Kegiatan manajemen usahatani salak meliputi; perencanaan (planning), pengorganisasian (organizing), pelaksanaan (actuating) dan pengawasan (controlling). Kegiatan tersebuat mualai dari perencanaan usaha, penyediaan sarana dan prasarana, budidaya tanaman, sampai dengan penanganan hasil dan pemasarannya dilakukan secara terintegrasi dan saling menunjang. Oleh karena itu diperlukan suatu manajemen dalam kegiatan usahatani, kegiatan manajemen usahatani yang dimaksud dari pemeliharan tanaman hingga pemasaran serta yang dapat merangkum faktor-faktor alam, modal, tenaga kerja, dan sarana/peralatan yang digunakan dalam usahatani. Hal ini menunjukan agar kegiatan manajemen usahatani salak di Subak Abian Kebon bisa berkembang dan mampu mengoptimalkan hasil pertanian demi kesejahteran petani.

\subsection{Rumusan Masalah}

Sesuai dengan latar belakang yang telah diuraikan di atas, maka yang menjadi rumusan masalah dalam penelitian ini adalah bagaimana kegiatan manajemen usahatani Salak Bali organik di Subak Abian Kebon Desa Nongan, Kecamatan Rendang, Kabupaten Karangasem? 


\subsection{Tujuan Penelitian}

Berdasarkan rumusan masalah di atas, maka tujuan dari penelitian ini adalah untuk mengetahui kegiatan manajemen usahatani Salak Bali organik di Subak Abian Kebon Desa Nongan, Kecamatan Rendang, Kabupaten Karangasem.

\section{Metoda Penelitian}

\subsection{Lokasi dan Waktu Penelitian}

Penelitian ini berlokasi di Subak Abian Kebon Desa Nongan, Kecamatan Rendang, Kabupaten Karangasem. Penentuan lokasi penelitian menggunakan metoda purposive, yaitu metoda penentuan lokasi yang dilakukan secara sengaja dengan pertimbangannya; (1) Desa Nongan merupakan salah satu kawasan penghasil salak, salak adalah salah satu produk unggulan yang dibudidayakan di Desa Nongan mengingat lahan pertanian salak terbentang luas di Desa Nongan dengan sebagaian besar daerahnya merupakan perkebunan yang memungkinkan adanya pengembangan usahatani salak, dan (2) Belum ada penelitian di Subak Abian Kebon mengenai manajemen usahatani salak.

\subsection{Jenis dan Sumber Data}

Jenis data yang digunakan dalam penelitian ini adalah data kuantitatif dan data kualitatif. Data kualitatif merupakan data yang berupa keadaan, proses, kejadian yang dinyatakan dalam bentuk perkata, tidak berupa angka yang dapat di hitung, seperti pemeliharan tanaman salak, penanganan hama dan penyakit tanaman, penanganan panen, penanganan pascapanen, pemasaran, sarana/peralatan usahatani, penjarangan, pemangkasan, pembumbunan dan pemupukan. Data kuantitatif merupakan data yang berupa angka-angka yang dapat diukur dalam satuan tertentu dan dapat dihitung secara statistik dan sistematis, penetapan biaya usahatani, penggunaan tenaga kerja, dan modal usahatani.

Sumber data yang digunakan dalam penelitian ini adalah data primer dan data sekunder. Data primer merupakan data yang diperoleh secara langsung dari sumbernya yaitu melalui wawancara dan pengisian daftar pertanyaan (kuesioner) kepada para responden (Sugiyono, 2011). Data primer yang diperlukan dalam penelitian ini adalah karakteristik responden yang meliputi nama, jenis kelamin, tingkat pendidikan, pekerjaan sampingan, dan luas lahan garapan. Selain itu data yang diperlukan adalah kegiatan manajemen usahatani salak yang berkaitan dengan fungsi manajemen perencanaan (planning), pengorganisasian (organizing), pelaksanaan (actuating), dan pengawasan (controlling). Data sekunder merupakan data yang berupa dokumendokumen yang diperoleh secara tidak langsung. Data sekunder dalam penelitian ini meliputi, artikel, literatur, jurnal, internet, dan dokumen subak abian. Data sekunder yang diperlukan dalam penelitian ini adalah keadaan umum Subak Abian Kebon seperti, profil subak dan keadaan geografis, struktur organisasi, sejarah, jumlah anggota Subak Abian Kebon, dan informasi lain yang mendukung permasalahan penelitian.

\subsection{Metode Pengumpulan Data}

Metode yang digunakan oleh peneliti untuk mengumpulkan data sebagai berikut. Wawancara (interview) adalah teknik pengumpulan data dengan melakukan tanya jawab kepada responden yaitu kepada anggota Subak Abian Kebon. Wawancara mendalam (indepth interview) merupakan proses memperoleh keterangan untuk tujuan penelitian dengan cara tanya jawab dan tatap muka kepada ketua subak. Observasi merupakan 
teknik pengumpulan data yang dilakukan dengan pengamatan secara langsung pada objek penelitian yakni pengamatan langsung pada daerah penelitian yaitu Subak Abian Kebon. Dokumen biasanya berbentuk tulisan, gambar, atau karya-karya monumental dari seseorang.

\subsection{Instrumen Penelitian}

Instrumen penelitian merupakan suatu alat yang dapat digunakan oleh peneliti untuk mengumpulkan data dan dapat mempermudah pekerjaan dengan hasil yang lebih baik. Instrumen penelitian juga dapat membantu peneliti untuk mendapatkan data secara lebih cermat, lengkap dan sistematis, sehingga dapat lebih mudah untuk diolah (Arikunto, 2012).

Instrument pengumpulan data penelitian ini menggunakan daftar pertanyaan (kuesioner) dan alat potret (kamera) untuk mendokumentasikan kegiatan atau kondisi lapangan. Kuesioner merupakan merupakan instrument pegumpulan data yang berisikan pernyataan terstruktur tertulis yang digunakan untuk memproleh informasi dari responden. Instrumen penelitian pada umumnya perlu mempunyai dua syarat penting yaitu valid dan reliabel (Sukardi, 2003). Kuesioner digunakan untuk mendapat informasi dari responden maka perlu terlebih dahulu dilakukan uji kesahihan dan keterandalan.

\subsection{Penentuan Populasi dan Sampel Penelitan}

Menurut Sugiyono (2010), populasi adalah wilayah generalisasi yang terdiri atas objek/subjek yang mempunyai kualitas dan karakteristik tertentu yang ditetapkan oleh penelitian untuk dipelajari dan kemudian ditarik kesimpulan. Berdasarkan definisi di atas, populasi merupakan objek atau subjek yang berada pada suatu wilayah dan memenuhi syarat tertentu yang berkaitan dengan masalah penelitian. Populasi penelitian ini adalah anggota Subak Abian Kebon dengan jumlah anggota sebanyak 76 orang.

Sampel adalah sebagian dari jumlah dan karakteristik yang dimiliki oleh populasi tersebut. Metode yang digunakan adalah simple random sampling yaitu cara pemilihan responden dimana anggota populasi dipilih satu per satu secara random (semua mendapatkan kesempatan yang sama untuk dipilih). Perhitungan pengambilan sampel mengunakan rumus Slovin sehingga jumlah responden penelitian ini sebanyak 44 orang.

\subsection{Analisis Data}

Menurut Sugiyono (2009), analisis data adalah proses mencari dan menyusun data yang diperoleh dari hasil wawancara, catatan lapangan, dan bahan-bahan lain secara sistematis sehingga mudah dipahami dan temuannya dapat diinformasikan kepada orang lain. Penelitian ini digunakan analisis data deskriptif kualitatif. Data yang diperoleh selanjutnya diolah dan ditabulasikan dalam bentuk tabel dan dihitung frekuensi serta persentasenya dengan bantuan skoring mengunakan skala ordinal (berjenjang lima).

\section{Hasil dan Pembahasan}

\subsection{Manajemen Usahatani Salak Balik Organik di Subak Abian Kebon}

Manajemen usahatani menurut Hernanto, (1989) merupakan kemampuan petani menentukan, mengorganisasikan, dan mengkoordinasikan faktor-faktor produksi yang dikuasainya sebaik-baiknya dan mampu memberikan produksi pertanian sebagaimana yang diharapkan. Keberhasilan suatu usahatani sangat ditentukan dari keberhasilan manajemen yang dijalankan dalam usaha tersebut. 
Manajemen usahatani yang dimaksud dalam penelitian ini dengan memanfaatkan fungsi manajemen yang meliputi: perencanaan (planning), pengorganisasian (organizing), pelaksanaan (actuating), dan pengawasan (controlling). Hasil penelitian dari manajemen usahatani di Subak Abian Kebon tampak pada Tabel 1 di bawah ini.

Tabel 1.

Pencapaian Skor Manajemen Usahatani Salak Bali Organik

di Subak Abian Kebon, dilihat dari Rata-Rata Pencapaian Skor untuk Masing-Masing Variabel,Tahun 2017

\begin{tabular}{|c|c|c|c|}
\hline No & Fungsi Manajemen & Pencapaian skor & Kategori \\
\hline 1 & Perencanaan & 4,0 & Baik \\
\hline 2 & Pengorganisasian & 4,0 & Baik \\
\hline 3 & Pelaksanaan & 4,3 & Sangat baik \\
\hline \multirow[t]{2}{*}{4} & Pengawasan & 3,4 & Sedang \\
\hline & Rata-rata manajemen usahatani & 3,9 & Baik \\
\hline
\end{tabular}

Tabel 1 dapat dilihat bahwa rata-rata pencapaian skor manajemen usahatani salak dengan skor sebesar 3,9 termasuk dalam kategori baik. Pencapaian skor 3,9 dari 5,0 mengartikan kegiatan manajemen usahatani salak di Subak Abian Kebon sudah mampu melaksanakan kegiatan manajemen dengan baik, meskipun dalam kegiatan manajemen mengalami beberapa hambatan seperti hasil produksi yang diperoleh petani setiap tahunnya semakin menurun dikarenakan tanaman yang sudah semakin tua.

Hasil penelitian menunjukkan bahwa pencapaian skor manajemen usahatani Salak Bali organik dalam perencanaan kegiatan usahatani termasuk dalam kategori baik dengan pencapaian skor rata-rata 4,0. Pencapaian skor manajemen usahatani dalam pengorganisasian mendapat skor rata-rata sebesar 4,0 termasuk dalam kategori baik. Pelaksanaan usahatani mendapat kategori sangat baik dengan pencapaian skor sebesar 4,3. Pengawasan usahatani mendapat skor sebesar 3,4 dengan kategori sedang. Kegiatan manajemen usahatani Salak menunjukkan, anggota subak secara umum sudah melaksanakan manajemen usahatani dengan baik untuk memenuhi kebutuhan dan kelangsungan hidup petani.

\subsubsection{Perencanaan Usahatani}

Perencanaan adalah penentuan jalan dan macam kegiatan yang telah ditentukan dan diproyeksikan terlebih dahulu untuk menimbulkan atau untuk mencapai suatu hasil yang diinginkan (Wiratmaja, 1987). Pencapaian skor perencanaan usahatani yang dimaksud dalam penelitian ini adalah skor penilaian responden terhadap perencanaan di Subak Abian Kebon yang terdiri dari pemeliharaan tanaman salak, penetapan tenaga kerja, penetapan biaya usahatani, penanganan hama dan penyakit tanaman, penanganan panen, penanganan pascapanen dan pemasaran. Pencapaian skor berdasarkan perencanaan usahatani tertuang pada Tabel 2 di bawah ini. 
Tabel 2.

Perencanaan Usahatani Salak Bali Organik di Subak Abian Kebon, Tahun 2017

\begin{tabular}{clcc}
\hline No & \multicolumn{1}{c}{ Indikator Perencanaan } & Rata-rata skor & Kategori \\
\hline 1 & Pemeliharaan tanaman salak & 4,2 & Baik \\
2 & Penetapan tenaga kerja & 4,2 & Baik \\
3 & Penetapan biaya usahatani & 4,0 & Baik \\
4 & Penanganan hama dan penyakit & 3,9 & Baik \\
& tanaman & & \\
5 & Penanganan panen & 4,0 & Baik \\
6 & Penanganan pascapanen & 3,8 & Baik \\
7 & Pemasaran & 3,7 & Baik \\
\hline & Rata-rata perencanaan usahatani & 4,0 & Baik \\
\hline
\end{tabular}

Tabel 1 hasil penelitian ini menunjukkan bahwa perencanaan usahatani di Subak Abian Kebon termasuk dalam kategori baik dengan total skor yaitu 4,0. Perencanaan merupakan penentuan terlebih dahulu apa yang harus dikerjakan dan siapa yang mengerjakan, serta dapat dilihat sebagai suatu proses kerangka kerja untuk mengambil keputusan dan penyusunan rangkaian tindakan di masa depan. Perencanaan usahatani terdiri dari tujuh indkator dianatarnya; pemeliharaan tanaman salak dengan skor sebesar 4,2 berada pada kategori baik, penetapan tenaga kerja dengan skor sebesar 4,2 berada pada kategori baik, penetapan biaya usahatani dengan skor sebesar 4,0 berada pada kategori baik, penanganan hama dan penyakit tanaman dengan skor sebesar 3,9 berada pada kategori baik, penanganan panen dengan skor 3,7 berada pada kategori baik, penanganan pascapanen dengan skor 3,8 berada pada kategori baik, dan pemasaran dengan skor 3,7 berada pada kategori baik.

\subsubsection{Pengorganisasian Usahatani}

Pencapaian skor pengorganisasian yang dimaksud dalam penelitian ini adalah skor penilaian responden terhadap pengorganisasian usahatani di Subak Abian Kebon dalam pengunaan tenaga kerja, disini petani mengkoordinir semua kegiatan dari pengunaaan tenaga kerja yang akan digunakan dalam pemeliharan tanaman salak. Pencapaian skor pengorganisasian dapat dilihat pada Tabel 3 di bawah ini.

Tabel 3.

Pencapaian Skor Pengorganisasian Usahatani Salak Bali Organik di Subak Abian Kebon Tahun 2017

\begin{tabular}{cccc}
\hline No & Indikator Pengorganisasian & $\begin{array}{c}\text { Pencapaian } \\
\text { Skor }\end{array}$ & Kategori \\
\hline 1 & Penggunaan tenaga kerja & 4,0 & Baik \\
\hline & Rata-rata pengorganisasian usahatani & 4,0 & Baik
\end{tabular}

Pencapaian skor pengorganisasian pada indikator penggunaan tenaga kerja dengan pencapain skor 4,0 berada pada kategori baik. Penggunaan tenaga kerja dalam melaksanakan kegiatan usahatani pada penelitian ini adalah tenaga kerja keluarga 
biasanya terdiri dari atas petani sebagai kepala keluarga, istri, dan anak yang berkesempatan melakukan pemelihara dalam melakukan kegitan usahatani. Petani berperan sebagai manajer akan berhadapan dengan berbagai alternatif yang harus diptuskan yang mana dipilih untuk diusahakan. Petani sebagai juru tani, harus menentukan jenis tanaman salak, menetukan cara-cara pemeliharan hingga pemasaran. Sebagai manusia biasa yang hidup dalam masyarakat, hidup sebagaimana artinya hidup dalam ikatan keluarga akan berusaha memenuhi kebutuhan keluarganya (A.T Mosher, 1987)

\subsubsection{Pelaksanaan}

Pelaksanaan adalah proses penerapan rencana-rencana usaha oleh petani dalam usahataninya. Petani sebagai manager untuk memimpin pelaksanaan kegiatan untuk usahataninya dibantu oleh keluarga dan tenaga kerja. Pencapaian skor berdasarkan pelaksanaan usahatani dapat dilihat pada Tabel 4 di bawah ini.

Tabel 4.

Pencapaian Skor Pelaksanaan Usahatani Salak Bali Organik di Subak Abian Kebon Tahun 2017

\begin{tabular}{clcc}
\hline No & \multicolumn{1}{c}{ Indikator Pelaksanaan } & $\begin{array}{c}\text { Pencapaian } \\
\text { Skor }\end{array}$ & Kategori \\
\hline 1 & Penjarangan & 4,3 & Sangat baik \\
2 & Pemangkasan tanaman & 4,3 & Sangat baik \\
3 & Penyiangan & 4,3 & Sangat baik \\
4 & Pembumbunan & 4,4 & Sangat baik \\
5 & Pemupukan & 4,3 & Sangat baik \\
6 & Pengendalian hama dan penyakit tanaman & 4,4 & Sangat baik \\
7 & Panen & 4,0 & Baik \\
8 & Pascapanen & 4,3 & Sangat baik \\
9 & Pemasaran & 4,0 & Baik \\
10 & Penerimaan inovasi & 4,2 & Baik \\
11 & Modal usahatani & 4,4 & Sangat baik \\
\hline & Rata-rata pelaksanaan usahatani & 4,3 & Sangat baik \\
\hline
\end{tabular}

Tabel 4 menunjukkan bahwa pencapaian skor di Subak Abian Kebon dalam pelaksanan penjarangan dengan skor 4,3 berada pada kategori sangat baik. Pelaksanaan penjarangan tanaman sudah dilakukan dengan baik. Penjarangan tanaman salak dilakukan dengan cara membersikan tandan-tandan yang muli rapat dilakukan penjarangan yang biasa dilakukan bulan ke 4 atau ke 5. Pencapaian skor pelaksanan penjarangan dengan skor 4,3 berada pada kategori sangat baik, pencapaian skor berdasarkan indikator pemangkasan tanaman dengan skor sebesar 4,3 berada pada kategori sangat baik, indikator penyiangan tanaman dengan skor 4,3 berada pada kategori sangat baik, pencapaian skor berdasarkan indikator pemupukan tanaman salak dengan skor 4,3 dengan kategori sangat baik, dan pencapaian skor berdasarkan indikator pengendalian hama dan penyakit dengan skor 4,3 berada pada kategori sangat baik

Skor tertinggi pada pengawasan usahatani adalah indikator pengembangan modal usahatani dengan skor 3,5 sedangkan skor terendah adalah indikator kualitas produksi dengan skor 3,3. Pengembangan modal usahatani cukup baik sedangkan skor terendah 
pada indikator kualitas produk buah salak, karena mutu dari buah salak dipengaruhi oleh umur tanaman.

\subsubsection{Pengawasan Usahatani}

Semua pelaksanaan kegiatan usahatani harus diawasi agar sesuai dengan perencanaan yang dibuat. Caranya adalah dengan melihat sumber daya yang ada dan menyelaraskan dengan tujuan pelaksanaan usahatani (A.T.Mosher, 1987).

Pencapaian skor pengawasan usahatani yang dimaksud dalam penelitian ini adalah skor penilaian responden terhadap pengawasan anggota subak di Subak Abian Kebon yang terdiri dari kualitas produk usahatani dan perkembangan modal usahatani. Pencapaian skor pengawasan usahatani anggota subak dapat dilihat pada Tabel 5 di bawah ini.

Tabel 5.

Pencapaian Skor Berdasarkan Pengawasan Usahatani Salak Bali Organik di Subak Abian Kebon, Tahun 2017

\begin{tabular}{llcc}
\hline No & Indikator Pengawasan & $\begin{array}{c}\text { Pencapaian } \\
\text { Skor }\end{array}$ & Kategori \\
& & 3,3 & Sedang \\
\hline 1 & Kualitas produk & 3,5 & Baik \\
\hline & Perkembangan modal usahatani & 3,4 & Sedang \\
\hline
\end{tabular}

Tabel 5 menunjukkan pencapaian skor pada indikator kualitas produk dikategorikan sedang dengan skor 3,3. Petani belum mampu memaksimalkan hasil kualitas produk. Secara empiris, responden menyatakan tanaman salak yang ada di subak sudah berumur puluhan tahun dan hasil produk yang dihasilkan kurang maksimal. Hasil panen buah salak yang semakin sedikit dan untuk ukuran buah yang dipanen lebih kecil. Kurangnya pengawasan pemeliharaan tanaman guna untuk mempertahankan kulitas produk buah salak.

Pencapaian skor pada pengembangan modal usahatani di Subak Abian Kebon dengan skor sebesar 3,5 berada pada kategori baik. Menurut responden pengelolaan dana dari usaha LM3 dari tahun 2014 hingga saat ini yang sudah berjalan dengan baik. Dana tersebut dikelola dan dikembangkan sebagai usaha simpan pinjam untuk seluruh anggota subak sehingga lebih bermanfaat dan menjadi lebih epektif .

Skor tertinggi pada pengawasan usahatani adalah indikator pengembangan modal usahatani dengan skor 3,5 sedangkan skor terendah adalah indikator kualitas produksi dengan skor 3,3. Pengembangan modal usahatani cukup baik sedangkan skor terendah pada indikator kualitas produk buah salak, karena mutu dari buah salak dipengaruhi oleh umur tanaman.

Pencapaian skor pengawasan usahatani di Subak Abian Kebon yang diproleh ratarata 3,4 dengan kategori sedang, dalam variabel pengawasan ini terdapat dua indikator yaitu: kualitas produk dan perkembangan modal usahatani. Pencapaian skor kualitas produk usahatani dengan kategori sedang. Hal ini dikarenakan petani belum mampu memaksimalkan hasil produk buah salak. Secara empiris, responden menyatakan tanaman salak yang ada di subak sudah berumur puluhan tahun dan hasil produk yang dihasilkan kurang maksimal. Hasil panen buah salak yang semakin sedikit. 
Pencapaian skor pada pengembangan modal usahatani di Subak Abian Kebon dengan skor sebesar 3,5 berada pada kategori baik. Hal ini menunjukan bahwa menurut responden pengelolaan dana dari usaha LM3 dari tahun 2014 hingga saat ini sudah berjalan dengan baik. Dana tersebut dikelola dan dikembangkan sebagai usaha simpan pinjam untuk seluruh anggota subak sehingga lebih bermanfaat dan menjadi lebih efektif. Menurut A.T.Mosher (1966), menyatakan bahwa sebagai seorang manajer, petani harus segera mengambil keputusan yang cepet dan tepat. Caranya adalah dengan melihat sumber daya yang ada dan menyelaraskan dengan tujuan pelaksanaan usahatani.

\section{Simpulan dan Saran}

\subsection{Simpulan}

Berdasarkan hasil penelitian yang telah dilakukan dapat disimpulkan bahwa, manajemen usahatani salak organik dalam pelaksanaan kegiatan usahatani di Subak Abian Kebon, Desa Nongan, Kecamatan Rendang, Kabupaten Karangasem termasuk kategori baik dengan rata-rata pencapaian skor 3,9. Kegiatan usahatani tersebut di ukur dari beberapa variabel dari fungsi manajemen yang meliputi: 1) Perencanaan usahatani dengan pencapaian skor 4,0 berada pada kategori baik, 2) Pengorganisasian usahatani dengan skor 4,0 berada pada kategori baik, 3) Pelaksanaan usahatani dengan pencapaian skor 4,3 dengan kategori sangat baik, dan 4) Pengawasan usahatani dengan pencapaian skor 3,4 dengan kategori sedang.

\subsection{Saran}

Berdasarkan pembahasan hasil penelitian dan kesimpulan maka dapat disarankan agar anggota subak mampu meningkatkan fungsi manajemen terutama dalam pengawsan usahatani sehingga dapa memaksimalkan kualitas produksi. Meningkatkan pengawasan kegiatan usahatani seperti meningkatkan pengawasan pada pelaksanaan usahatani dari pemupukan, penjarangan, dan pengendalian hama dan penyakit tanaman agar hasil produksi yang diperoleh bisa maksimal dan mendapatkan hasil sesuai dengan harapan.

\section{Ucapan Termakasih}

Terimakasih kepada kepala Desa Nongan, Kecamatan Rendang beserta jajaran atas izin yang telah diberikan kepada penulis, selanjutnya tidak lupa ucapan terimaksih kepada ketua Subak Abian Kebon Bapak Pade Gede Sudasta beserta petani anggota Subak Abian Kebon yang telah meluangkan waktu untuk penulis melakukan penelitian hingga termuat di e-jurnal.

\section{Daftar Pustaka}

A.T.Mosher. 1987. Menggerakkan dan Membangun Pertanian. Jakarta:Yasaguna. Arikunto, S. dkk. 2012. Penelitian Tindakan Kelas. Jakarta : Bumi Aksara.

BPS Kabupaten Provensi Bali. 2015. Luas Panen Tanaman Pangan dan Hortikultura Kabupaten Karangasem.

Dinas Kebudyaan Provensi Bali. 2006. Pembinaan Kelembagaan Petani Perkebunan di Provinsi Bali.

Hernanto, Fadholi. 1989. Ilmu Usahatani. Jakarta. PT. Penebar Swadaya.

Nazaruddin dan Regina, Kristiawati. 1992. Varietas Salak. Jakarta. PT. Penebar Swadaya. 
Sugiyono. 2009. Mengidentifikasi Potensi Budaya yang ada di Desa Sangsit Jagaraga dan Sawan Kecamatan Sawan Kabupaten Buleleng. \{Jurnal Online\}. Internet. http://www.pps.unud.ac.id/thesis/pdf_thesis/unud-251-1074479723-bab-iii.pdf. Diakses pada tangal 26 November 2016.

Sugiyono. 2010 Statistik untuk Pendidikan. Bandung: Alfabeta.

Sugiyono. 2011. Metode Penelitian Kuantitatif Kualitatif dan R\&D. Bandung: Alfabeta. Sukardi. 2003. Metodologi Penelitian Pendidikan. Jakarta:Bumi Aksara. 